\title{
EWOLUCJA BAZY EKONOMICZNEJ MAŁYCH MIAST WYBRANYCH WOJEWÓDZTW
}

\section{Streszczenie}

Celem prezentowanych badań było określenie wielkości, struktury oraz poziomu zróżnicowania bazy ekonomicznej, a także ich zmian w latach 2008-2015 w odniesieniu do małych miast województwa warmińsko-mazurskiego oraz podlaskiego. Uzyskane wyniki pozwalają stwierdzić, że czynnikami ograniczającymi rozwój tych miast są niewielkie rozmiary i niekonkurencyjna struktura bazy ekonomicznej.

Słowa kluczowe: małe miasta, baza ekonomiczna, wzrost gospodarczy

\section{Abstract \\ Urban economic base evolution of small cities in selected voivodships}

The aim of the presented research was to determine the size, structure and level of diversification of the economic base, as well as their changes in 2008-2015, in relation to small towns of the Warmia-Masuria and Podlaskie Voivodeships. The obtained results allow to conclude that the important factors limiting the development of these cities are the small size and uncompetitive structure of the economic base.

Keywords: small towns, economic base, economic growth

Województwa warmińsko-mazurskie oraz podlaskie należą do obszarów o najniższym poziomie wzrostu gospodarczego w Polsce. Jest to uwarunkowane wieloma czynnikami. Wśród nich należy z pewnością wymienić niski stopień rozwoju miejskiej sieci osadniczej. Liczba miast w obu województwach jest względnie niewielka, dodatkowo w jej strukturze dominują ośrodki o niewielkiej liczbie mieszkańców. Poza Olsztynem, Elblągiem i Białymstokiem brakuje też dużych ośrodków, które mogłyby odgrywać rolę regionalnych biegunów wzrostu gospodarczego. Oznacza to, że znaczna część obszaru tych województw znajduje się poza strefami funkcjonalnymi dużych miast. Tym samym dostęp do dóbr wyższego rzędu, 
oferowanych przez podmioty zlokalizowane w dużych ośrodkach miejskich, jest utrudniony lub ograniczony dla dużej części mieszkańców warmińsko-mazurskiego i podlaskiego.

Wobec powyższego rośnie znaczenie małych i średnich ośrodków miejskich w zapewnieniu odpowiedniej podaży tych dóbr, a także stymulowaniu wzrostu i rozwoju gospodarczego na poziomie lokalnym. Jednocześnie zwiększanie skali oraz unowocześnienie struktury produkcji wytwarzanej w tych ośrodkach umożliwiłoby podniesienie poziomu wzrostu gospodarczego funkcjonalnie powiązanych z nimi obszarów oraz całego regionu.

Przedstawione analizy koncentrowały się na wskazaniu czynników determinujących wzrost i rozwój gospodarczy małych miast województw warmińsko-mazurskiego i podlaskiego jako ważnych elementów systemów społeczno-gospodarczych obu regionów. Podstawę teoretyczną dla prowadzonych analiz stanowiła teoria miejskiej bazy ekonomicznej. Zgodnie z nią koniecznym warunkiem wzrostu gospodarczego ośrodków miejskich jest zwiększenie wartości produkcji wytwarzanej w sektorze egzogenicznym miejskiej gospodarki oraz zwiększenie komplementarności jej struktury ze strukturą gospodarki regionalnej i krajowej. Stąd w pracy określono wielkość i strukturę bazy ekonomicznej małych miast województw warmińsko-mazurskiego oraz podlaskiego oraz ich zmiany w latach 2008-2015. Uzyskane wyniki pozwoliły na wskazanie zarówno charakterystycznych uwarunkowań i ograniczeń wzrostu gospodarczego małych ośrodków miejskich położonych w tych regionach, jak też czynników determinujących procesy wzrostu gospodarczego obu uwzględnionych w badaniu województw.

\section{Cel i metody badawcze}

Celem prezentowanych badań było określenie wielkości, struktury oraz poziomu zróżnicowania bazy ekonomicznej, a także ich zmian w latach 2008-2015 w odniesieniu do małych miast województw warmińsko-mazurskiego oraz podlaskiego. Uwzględniając znaczenie małych ośrodków miejskich w funkcjonowaniu systemów społeczno-gospodarczych obu województw, realizacja powyższego celu może dać także podstawy do oceny, czy istniejące niekorzystne dysproporcje rozwojowe między tymi regionami a resztą kraju były uwarunkowane czynnikami związanymi z ewolucją miejskiej bazy ekonomicznej.

Dla określenia wielkości sektora bazy ekonomicznej wykorzystano metody pośrednie, opierające się na danych o liczbie pracujących w podziale na działy i sekcje gospodarki. $\mathrm{W}$ tym celu obliczono wskaźnik nadwyżki pracowników $\left(\mathrm{W}_{\mathrm{NP}}\right)$ według wzoru [Sokołowski, 2008]:

$$
\mathrm{W}_{\mathrm{NP}}=\mathrm{ZiM}-\left(\mathrm{ZM} \times \frac{Z i R}{Z R}\right)
$$


ZiM - zatrudnienie w działalności $i$ na danym obszarze,

$\mathrm{ZM}$ - całkowite zatrudnienie na danym obszarze,

$\mathrm{ZiR}$ - zatrudnienie $\mathrm{w}$ działalności $i \mathrm{w}$ regionie,

ZR - całkowite zatrudnienie w regionie.

Powyższy wskaźnik informuje, o ile faktyczne zatrudnienie w działalności $i$ na badanym obszarze odbiega od poziomu zatrudnienia wyznaczonego przez przeciętny odsetek zatrudnionych $\mathrm{w}$ tej działalności w regionie stanowiącym punkt odniesienia. Dodatnie wartości zaobserwowane dla działalności $i$ wskazują, że tworzy ona sektor egzogeniczny. Wysokie wartości wskaźnika nadwyżki pracowników świadczą o dużym znaczeniu danej działalności nie tyle w skali regionu, ile dla samej jednostki.

Stopień dywersyfikacji bazy ekonomicznej określono, obliczając wartość wskaźnika Amemiya, według wzoru [Sokołowski, 2008; Knapik, 2010]:

$$
\mathrm{IED}=\sum_{i=1}^{m} \frac{m}{m-1}\left(\frac{Z \operatorname{Zegz} i M j}{Z \operatorname{Zegz} M j}-\frac{1}{m}\right)^{2}
$$

IED - indeks ekonomicznej dywersyfikacji sektora egzogenicznego miasta, $\mathrm{m}$ - liczba działalności (sekcji) wykorzystana w analizie (19),

Zegz $i \mathrm{Mj}$ - zatrudnienie egzogeniczne w działalności $i$ w mieście $\mathrm{Mj}$,

Zegz $\mathrm{Mj}$ - całkowite zatrudnienie egzogeniczne w działalności $i$ w mieście Mj.

Indeks IED przyjmuje wartości z przedziału od 0 do 1 , przy czym w prezentowanych analizach uzyskane wyniki przemnożono przez 1000, co pozwoliło na zaprezentowanie ich w bardziej przystępnej formie. Niskie wartości wskazują na występowanie zróżnicowanej struktury zatrudnienia i produkcji. Wysokie wartości wskazują z kolei na mało zróżnicowaną strukturę zatrudnienia (wartość równa 1000 oznacza skupienie całego zatrudnienia egzogenicznego tylko w jednej sekcji) [Knapik, 2010]. W zależności od wartości obliczonego wskaźnika wyróżnia się cztery poziomy dywersyfikacji bazy ekonomicznej w mieście [Knapik, 2010]:

$-0<$ IED $\leq 250$ - struktura mocno zróżnicowana;

$-250<$ IED $\leq 500$ - struktura zróżnicowana;

$-500<$ IED $\leq 750$ - struktura jednorodna;

$-750<$ IED $\leq 1000$ - struktura mocno jednorodna.

Podstawą obliczeń były dane o liczbie pracujących ${ }^{1} \mathrm{w}$ głównym miejscu pracy (z dn. 31 grudnia) z uwzględnieniem wszystkich przedsiębiorstw zarejestrowanych w mieście w podziale na sekcje PKD 2007. Jako punkt odniesienia dla obliczeń wielkości nadwyżki pracujących przyjęto strukturę zatrudnienia w regionie ${ }^{2}$.

1 Mimo odmiennego sposobu definiowania i tym samym obliczania przez GUS zasobu pracujących i zatrudnionych w pracy oba pojęcia są używane zamiennie.

2 Wybór gospodarki regionalnej jako punktu odniesienia dla obliczenia wielkości bazy ekonomicznej miast wynika z ograniczeń metodycznych zastosowanych wskaźników. Jak pokazują wyniki badań porównawczych opisanych m.in. przez Jerczyńskiego [1971] i Thulina [2014], przyjęcie 
Okres analizy obejmuje lata 2008 i 2015 . Był on podyktowany dostępnością porównywalnych danych statystycznych, które zakupiono w Departamencie Informacji Głównego Urzędu Statystycznego.

\section{Znacznie małych miast w rozwoju lokalnym i regionalnym}

Mimo względnie małej populacji i w konsekwencji niewielkiego potencjału społeczno-gospodarczego małe miasta mogą stanowić istotne ogniwa systemów osadniczych oraz gospodarczych. Ich względnie równomierne rozmieszczenie w przestrzeni jest także czynnikiem sprzyjającym efektywności gospodarczej, równości społecznej oraz zrównoważonemu gospodarowaniu zasobami przyrodniczymi i energetycznymi [Korcelli, 2007]. Znaczenie małych i średnich ośrodków miejskich w rozwoju lokalnym i regionalnym jest tym większe im sieć ośrodków miejskich jest słabiej rozwinięta, a poziom urbanizacji niższy. W pracach badawczych prowadzonych w ramach Europejskiej Sieci Obserwacyjnej Planowania Przestrzennego (ESPON) podkreśla się, że w tego typu obszarach, znajdujących się poza strefą odziaływania dużych ośrodków miejskich, to miasta małej i średniej wielkości powinny gwarantować dostęp do pełnej palety usług wyższego rzędu. Chodzi tu przede wszystkim o usługi związane z: administracją, edukacją (także w zakresie szkolnictwa wyższego), ochroną zdrowia, opieką społeczną, wsparciem biznesu (targi i kongresy handlowe) oraz innymi funkcjami o charakterze ponadlokalnym [Szlachta, 2011].

Pierwotnie najważniejsze funkcje małych i średnich miast były związane głównie $\mathrm{z}$ handlem i rzemiosłem. $\mathrm{Z}$ upływem czasu dołączyły do nich także funkcje administracyjne, obronne i religijne [The Role of..., 2006]. Rozwój cywilizacyjny i związany z nim postęp technologiczny oraz stały wzrost poziomu rozwoju społeczno-gospodarczego spowodowały, że rola małych i średnich miast ewoluowała. Współcześnie wyróżnia się cztery grupy funkcji pełnionych przez ośrodki miejskie małej i średniej wielkości [Elsasser, 1998]:

1. Podażowe - ich istota polega na sprzedaży produktów i usług mieszkańcom okolicznych obszarów. Ich zasięg przestrzenny zwykle ogranicza się do otaczających obszarów wiejskich. Jednocześnie funkcje te są istotną determinantą rozwoju obszarów znajdujących się w strefie przestrzennego oddziaływania miasta.

2. Mieszkaniowe - polegają na zapewnieniu odpowiedniej liczby budynków i lokali mieszkalnych dla mieszkańców i użytkowników miasta. W tym wymiarze małe miasta tworzą swego rodzaju kontinuum między przestrzenią wielkomiejską a wiejską, co pozwala na połączenie korzyści wynikających

zbyt małego obszaru (w tym wypadku np. powiatu) jako punktu odniesienia niesie ze sobą ryzyko nadmiernego zawyżenia wielkości sektora egzogenicznego. Odwrotnie - przyjęcie zbyt dużej przestrzennej jednostki odniesienia (np. kraju) może prowadzić do zaniżenia wielkości zatrudnienia egzogenicznego. 
z zamieszkania w dużym mieście z zaletami życia na obszarach niezurbanizowanych.

3. Kształtowanie lokalnego rynku pracy - podmioty zlokalizowane na obszarze małych i średnich miast zgłaszają popyt na pracowników także $\mathrm{z}$ otaczających miasto obszarów wiejskich. W tym aspekcie stanowią one dodatkowe źródło dochodów dla ludności wiejskiej, przyczyniając się do restrukturyzacji i dywersyfikacji produkcji na wsi.

4. Kulturalne - składają się na nie wszelkiego rodzaju działalności związane z zaspokojeniem popytu na uczestnictwo w kulturze, usługi wypoczynkowe i turystyczne. Realizacja tych funkcji w niektórych małych i średnich miastach stanowi dominująca część ich bazy ekonomicznej, stanowiąc tym samym podstawę rozwoju społeczno-gospodarczego.

Sprawna, efektywna realizacja powyższych funkcji jest jednocześnie zarówno jedną z determinant, jak i wskaźników wzrostu poziomu rozwoju społeczno-gospodarczego małych miast. Co ważne, ewolucja współczesnej gospodarki w kierunku gospodarki opartej na wiedzy i innowacjach oraz w konsekwencji zmiana paradygmatów gospodarowania stwarzają przed małymi i średnimi miastami realne szanse na zwiększenie ich wpływu na przebieg procesów gospodarczych i zdynamizowanie własnego rozwoju. W realiach nowego paradygmatu gospodarczego, tzw. postfordyzmu, wzrost gospodarczy w mniejszym stopniu zależy od zasobności gospodarek lokalnych, regionalnych i krajowych w proste zasoby naturalne, od wielkoseryjnej produkcji przemysłowej czy od liczby mieszkańców. Czynniki te faworyzowały duże ośrodki miejskie. Większego znaczenia nabiera natomiast zdolność do szybkiej adaptacji do dynamicznie zmieniających się warunków rynkowych, elastycznego popytu oraz zmieniającego się otoczenia technologiczno-organizacyjnego. Potencjał gospodarczy miast, determinanty ich rozwoju zależą coraz bardziej od stopnia ich integracji z krajową i międzynarodową siecią ośrodków miejskich, jakości i dostępności kapitału ludzkiego i społecznego oraz elastycznej specjalizacji (flexible specialisation) w produkcji produktów i usług [Messerli, 1998].

Konsekwencją tych zmian może - choć nie musi - być spłaszczenie hierarchii ośrodków miejskich, polegające na spadku znaczenia dużych miast, o dominującej funkcji przemysłowej, na rzecz ośrodków małych i średnich. Specyficzna struktura gospodarcza, społeczna i przestrzenna małych i średnich miast pozwala im bowiem na szybsze i bardziej efektywne dostosowywanie się do zmieniających się uwarunkowań gospodarczych. Ponadto jakość życia w tego typu ośrodkach nie musi istotnie odbiegać od warunków właściwych dużym miastom. W tym celu konieczna jest jednak zarówno obecność niezbędnej infrastruktury ekonomicznej i społecznej, jak też nowoczesna struktura działalności gospodarczej oraz funkcji pełnionych przez małe i średnie ośrodki miejskie [Bogdański, 2017]. Ostatnia $\mathrm{z}$ wymienionych kwestii w odniesieniu do małych miast województw warmińsko-mazurskiego i podlaskiego będzie przedmiotem analiz opisanych w pracy.

Powyższa teza znajduje swoje potwierdzenie w danych statystycznych odzwierciedlających dynamikę wzrostu gospodarczego wybranych regionów (na poziomie NUTS2) Unii Europejskiej (dalej: UE). W latach 2001-2008 spośród wszystkich 
regionów tzw. starej Unii, czyli państw członkowskich UE przed 2004 rokiem, do najszybciej rozwijających się obszarów należały te, w których strukturze osadniczej dominowały miasta małe i średnie. Ta zależność była obserwowana takżechoć z mniejszym natężeniem - dla wszystkich regionów UE [David i in., 2013]. Dzieje się tak między innymi dlatego, że w małych i średnich miastach istniejąca infrastruktura ekonomiczna i społeczna jest wykorzystywana bardziej efektywnie niż w miastach dużych. Jednocześnie prowadzenie działalności gospodarczej w tego typu ośrodkach wiąże się z mniejszymi efektami zewnętrznymi w postaci niekorzyści aglomeracji, których przejawem są między innymi: wysokie czynsze, wysokie płace, przeludnienie i problemy komunikacyjne [Grossmann i in., 2013].

\section{Baza ekonomiczna i struktura funkcjonalna a rozwój ośrodków miejskich}

Zgodnie z teorią miejskiej bazy ekonomicznej wszystkie rodzaje działalności gospodarczej prowadzonej w ośrodku miejskim dzieli się na dwa sektory: egzogeniczny (podstawowy, miastotwórczy) oraz endogeniczny (obsługowy, uzupełniający). W skład sektora egzogenicznego wchodzą te rodzaje działalności prowadzonych na terenie miasta, których efekty w postaci gotowych produktów i usług są sprzedawane na rynkach poza miastem. Sektor endogeniczny z kolei jest związany z produkcją dóbr zaspokajających potrzeby mieszkańców i użytkowników miasta. Dobra te są zatem wytwarzane i sprzedawane lokalnie [Knapik, 2010].

W teorii bazy ekonomicznej miasto ujmowane jest w sposób całościowy: jako system wzajemnie ze sobą powiązanych podmiotów, przede wszystkim przedsiębiorstw i gospodarstw domowych. Stąd wzrost skali i zakresu działalności prowadzonej w jednym z sektorów produkcji inicjuje wzrost drugiego sektora. Katalizatorem rozwoju miast jest wzrost produkcji wytwarzanej w ramach sektora egzogenicznego. Prowadzi to do wzrostu dochodów podmiotów zaangażowanych w działalność podstawową, co z kolei zwiększa efektywny popyt konsumpcyjny $\mathrm{i}$ inwestycyjny wewnątrz miasta, a w rezultacie stymuluje wzrost produkcji wytwarzanej w ramach sektora endogenicznego [Sokołowski, 2008]. Sprzyja to również napływowi nowych przedsiębiorstw. W efekcie produkcja globalna w mieście zwiększa się, maleje bezrobocie, rosną dochody gospodarstw domowych, przedsiębiorstw, budżetów władz miejskich. Pierwotny impuls w postaci wzrostu skali działalności egzogenicznej uruchamia procesy mnożnikowe, których globalny efekt będzie większy niż początkowo podjęta działalność. Im większy wzrost dochodów z działalności egzogenicznej, tym większy jest potencjał dla bardziej dynamicznego wzrostu gospodarczego miast [Rutland, O'Hagan, 2007; Stawasz, 2016].

Mimo relatywnie długiej tradycji (za autora koncepcji miejskiej bazy ekonomicznej uważa się niemieckiego ekonomistę, historyka i geografa ekonomicznego Wernera Sombarta, żyjącego na przełomie XIX i XX wieku) i zmieniających się paradygmatów gospodarowania $\mathrm{w}$ literaturze przedmiotu można spotkać się z poglądem, że istnieją wyłącznie dwie sprawdzone teorie w sposób całościowy 
opisujące i wyjaśniające determinanty funkcjonalnego rozwoju miast: teoria ośrodków centralnych oraz teoria bazy ekonomicznej [Walkiewicz, 2006].

Jak już wspomniano, rozwój gospodarczy miast jest także częściowo zdeterminowany przez komplementarność funkcji miast ze strukturą gospodarki krajowej i międzynarodowej. Stąd ważnym elementem analiz determinant wzrostu i rozwoju gospodarczego miast powinna być analiza ich struktury funkcjonalnej.

Funkcje miast zwykle definiuje się w kontekście działalności mających charakter dominujący, stanowiących podstawę ich potencjału ekonomicznego, decydujących o ich rozwoju [Czornik, 2004]. Są to najważniejsze rodzaje działalności (pracy) wykonywanej przez jego mieszkańców. Można do nich zaliczyć między innymi: przemysł, komunikację, administrację, handel, kulturę, oświatę itd. [Brol, 2004]. Przyjmując tę perspektywę, liczbę funkcji pełnionych przez miasto można określić na podstawie liczby sekcji PKD, w których zanotowano nadwyżkę zatrudnionych lub pracujących wobec analogicznych wielkości w regionie lub kraju [Suliborski, 2002]. Stanowi to z kolei podstawę dla dokonania typologii funkcjonalnej miast, która według Kazimierza Dziewońskiego powinna opierać się na badaniu między innymi następujących zagadnień [Przybyła, 2010]:

- struktury obecnych funkcji miasta (wyrażającej bieżące dostosowanie gospodarki miasta do ogólnych potrzeb społeczeństwa oraz potencjału środowiska geograficznego),

- wielkości oraz struktury przestrzennej miasta (mierzonych liczbą mieszkańców miasta oraz podstawową organizacją rozmieszczenia ludności),

- etapu rozwojowego miasta (określonego dynamiką wzrostu miasta w okresie analizy oraz w okresach poprzedzających).

Z punktu widzenia stymulowania wzrostu gospodarczego miast współcześnie za najbardziej korzystną strukturę funkcji należy uznać taką, w której dominującą rolę odgrywają usługi rynkowe. Wynika to faktu, że w porównaniu z produkcją przemysłową, usługi charakteryzują się wyższą wartością dodaną, w związku z czym ich rozwój generuje silniejsze impulsy rozwojowe dla całej gospodarki miejskiej. Ponadto przedsiębiorstwa usługowe, te działające w sferze usług zarówno rynkowych, jak i nierynkowych, są znacznie silniej powiązane z lokalną gospodarką [Christofakis, Gkouzos, 2014].

\section{Wyniki badań}

Badaną zbiorowość stanowiło w sumie 66 małych miast położonych w województwach warmińsko-mazurskim (38 małych ośrodków miejskich) oraz podlaskim (28 małych miast). Zarówno województwo warmińsko-mazurskie, jak i województwo podlaskie należą do najsłabiej zurbanizowanych regionów w Polsce. W porównaniu $\mathrm{z}$ innymi województwami liczba miast $\mathrm{w}$ tych regionach jest względnie niewielka, co przekłada się na małą gęstość ośrodków miejskich - powierzchnia województwa $\mathrm{w} \mathrm{km}^{2}$ przypadająca na jedno miasto $\mathrm{w}$ warmińsko-mazurskim w badanym okresie wynosiła $493,7 \mathrm{~km}^{2}$, a w podlaskim $504,7 \mathrm{~km}^{2}$, 
przy średniej krajowej na poziomie $350,54 \mathrm{~km}^{2}$. Miasta duże i średnie stanowią niewielką część miejskiej sieci osadniczej tych regionów. W warmińsko-mazurskim w latach 2008-2015 jedynie dwa ośrodki (Olsztyn i Elbląg) charakteryzowały się liczbą mieszkańców przekraczającą 100 tys., co pozwala na określenie ich jako ośrodki duże. Z kolei w województwie podlaskim jedynie stolica tego regionu - Białystok - spełniała to kryterium. Miast średnich, o liczbie mieszkańców w granicach 20-100 tys., w warmińsko-mazurskim było dziewięć, a w podlaskim pięć. W 2008 roku małe miasta województwa warmińsko-mazurskiego zamieszkiwało 279391 osób, co stanowiło 19,6\% wszystkich mieszkańców województwa oraz 32,7\% ogółu ludności miejskiej. W roku 2015 liczba mieszkańców małych ośrodków miejskich zmalała do 279 093, co stanowiło 19,4\% wszystkich mieszkańców województwa oraz 32,8\% mieszkańców miast w tym regionie. Z kolei w województwie podlaskim liczba mieszkańców małych ośrodków miejskich w roku 2008 wyniosła 159.652 , co stanowiło 13,4\% mieszkańców regionu oraz $22,5 \%$ wszystkich mieszkańców miast w tym województwie. W roku 2015 liczba mieszkańców małych ośrodków miejskich również zmalała, do poziomu 159 165, jednak ich udział nie tylko w całkowitej populacji województwa, lecz także populacji miejskiej się nie zmienił.

Wobec niskiego poziomu rozwoju miejskiej sieci osadniczej w obu regionach rola małych ośrodków miejskich w dostarczaniu dóbr i usług, także usług wyższego rzędu, dla ludności tych województw jest relatywnie większa niż w regionach silniej zurbanizowanych. Dotyczy to szczególnie tych obszarów, które znajdują się poza zasięgiem funkcjonalnego oddziaływania miast dużych i średnich. Zwiększa to także znaczenie małych miast w stymulowaniu wzrostu i rozwoju gospodarczego na poziomie lokalnym i regionalnym. Tym samym analiza wielkości i struktury bazy ekonomicznej tych ośrodków nabiera większego znaczenia.

W tabeli 1 przedstawiono dane o przeciętnej wielkości bazy ekonomicznej (w os.) w obu badanych regionach w latach 2008 i 2015. Dane te przedstawiono nie tylko w odniesieniu do grupy miast małych, ale także - dla uzyskania pełniejszej perspektywy badawczej - do grup miast dużych i średnich. Szczegółowe dane o wielkości bazy ekonomicznej w poszczególnych małych miastach obu województw przedstawiono natomiast w załączniku 1.

Porównując przeciętną liczbę pracujących w sektorze egzogenicznym małych miast, można zauważyć dość istotne różnice między badanymi województwami. W obu analizowanych latach wielkość bazy ekonomicznej w województwie warmińsko-mazurskim w ujęciu bezwzględnym była blisko dwukrotnie większa niż w województwie podlaskim. W ujęciu względnym różnice te były nieco mniejsze. Jednocześnie tylko w województwie warmińsko-mazurskim przeciętna liczba pracujących w sektorze działalności podstawowej małych miast w roku 2015 była większa niż na początku badanego okresu.

W przypadku województwa warmińsko-mazurskiego największym zatrudnieniem nadwyżkowym w obu badanych latach charakteryzowała się Lubawa. W roku 2008 w sektorze egzogenicznym pracowało tam 2212 osób, natomiast w roku 2015 liczba ta wzrosła do 2442 , co stanowiło odpowiednio $23,23 \%$ i $24,22 \%$ całej populacji miasta. Zdecydowaną większość pracujących (95\% w roku 2008 i 100\% 
w roku 2015) stanowili zatrudnieni w sekcji C PKD 2007, czyli w przetwórstwie przemysłowym. Lubawa jest jednym z największych ośrodków produkcji mebli w regionie. Dostępność surowca, istniejące tradycje oraz obecność wykwalifikowanej kadry stały się podstawą specjalizacji tego miasta i wzrostu zatrudnienia egzogenicznego.

Tabela 1

Przeciętna wielkość bazy ekonomicznej w grupach miast województw warmińsko-mazurskiego i podlaskiego w latach 2008 i 2015

\begin{tabular}{|l|c|c|c|c|}
\hline \multirow{2}{*}{ Wielkość miast } & \multicolumn{4}{|c|}{ Województwo warmińsko-mazurskie } \\
\cline { 2 - 5 } & $\begin{array}{c}\text { Wielkość bazy } \\
\text { ekonomicznej } \\
\text { (osoby) }\end{array}$ & $\begin{array}{c}\text { Baza } \\
\text { ekonomiczna jako } \\
\text { \% ludności }\end{array}$ & $\begin{array}{c}\text { Wielkość bazy } \\
\text { ekonomicznej } \\
\text { (osoby) }\end{array}$ & $\begin{array}{c}\text { Baza } \\
\text { ekonomiczna jako } \\
\% \text { ludności }\end{array}$ \\
\hline Małe & 314 & 4,16 & 332 & 4,50 \\
\hline Średnie & 850 & 2,82 & 837 & 2,79 \\
\hline Duże & 6548 & 4,02 & 6538 & 4,02 \\
\hline \multirow{5}{*}{ Wielkość miast } & $\begin{array}{c}\text { Wielkość bazy } \\
\text { ekonomicznej } \\
\text { (osoby) }\end{array}$ & $\begin{array}{c}\text { Bojewództwo podlaskie } \\
\text { ekoniczna jako } \\
\text { \% ludności }\end{array}$ & $\begin{array}{c}\text { Wielkość bazy } \\
\text { ekonomicznej } \\
\text { (osoby) }\end{array}$ & $\begin{array}{c}\text { Bazonomiczna jako } \\
\text { \% ludności }\end{array}$ \\
\hline Małe & 167 & 2,92 & 158 & 2,78 \\
\hline Średnie & 1186 & 3,73 & 1217 & 3,47 \\
\hline Duże & 7506 & 2,55 & 9890 & 3,34 \\
\hline
\end{tabular}

Źródło: obliczenia i opracowanie własne na podstawie danych GUS.

Najmniejszymi rozmiarami bazy ekonomicznej w warmińsko-mazurskim charakteryzowały się z kolei w 2008 roku Ryn (siedem osób, czyli 0,24\% ludności), a w roku 2015 Tolkmicko (21 osób, czyli 0,84\% mieszkańców). Należą one do najmniejszych ośrodków w regionie, pozbawionych dużych pracodawców, które szans rozwoju mogą upatrywać w turystyce. Ze względu jednak na niski poziom rozwoju infrastruktury turystycznej ta działalność charakteryzuje się dużymi wahaniami sezonowymi, przez co nie może stać się podstawowym elementem potencjału gospodarczego. Największy przyrost bazy ekonomicznej zaobserwowano w Mikołajkach (o 386 osób, co stanowiło 10,05\% ludności w roku 2008). Przyczyniły się do tego głównie inwestycje w rozwój bazy turystycznej (i tym samym wzrost zatrudnienia w tej działalności) w mieście i okolicach. Największy spadek dotyczył Ornety (-157 osób, co stanowi 1,65\% ludności).

Spośród małych miast województwa podlaskiego w 2008 roku największymi rozmiarami bazy ekonomicznej charakteryzowały się Łapy, w których 615 osób 
(3,8\% ludności miasta) było zatrudnionych w sektorze egzogenicznym, w tym $90 \% \mathrm{z}$ nich w przetwórstwie przemysłowym. W kolejnych latach w związku ze stopniowym ograniczaniem zatrudnienia w miejscowej cukrowni oraz Zakładach Naprawczych Taboru Kolejowego (najwięksi pracodawcy w mieście) nadwyżka pracowników sukcesywnie malała. W roku 2015 największymi rozmiarami bazy ekonomicznej wśród małych miast podlaskiego charakteryzowała się już Sokółka (715 osób, czyli 3,85\% mieszkańców miasta). Ponad 77,6\% tego zatrudnienia generowało przetwórstwo przemysłowe (produkcja maszyn rolniczych oraz stolarki okiennej). Najmniejszymi rozmiarami sektora egzogenicznego cechowały się natomiast Rajgród (0 osób) w roku 2008 oraz Knyszyn w roku 2015 (7 osób). W analizowanym okresie największy wzrost liczby pracujących w działalności podstawowej zaobserwowano w Choroszczy (o 374 osoby, co stanowiło 6,4\% liczby mieszkańców z 2008 roku), natomiast największy spadek dotyczył Łap (o 275 osób, czyli 1,6\% mieszkańców).

Należy zatem podkreślić, że w obu badanych województwach rozmiary sektora egzogenicznego małych miast były relatywnie niewielkie, choć między poszczególnymi miastami różnice były znaczące. Dotyczy to wartości zarówno bezwzględnych, jak i względnych. W opinii autora świadczy to przede wszystkim o niewielkim potencjale gospodarczym i niskiej konkurencyjności badanych ośrodków.

W literaturze z zakresu analiz bazy ekonomicznej dominuje pogląd, że wraz ze wzrostem liczby mieszkańców udział zatrudnienia egzogenicznego w ogólnym zatrudnieniu maleje [Przybyła, 2010]. Tymczasem w odniesieniu do badanych ośrodków nie można było obserwować powyższej zależności. Jedynie w warmińsko-mazurskim przeciętna względna wielkość sektora egzogenicznego w małych miastach była większa niż w innych grupach miast. Obserwowane różnice, szczególnie w odniesieniu do miast dużych, były jednak niewielkie.

Ważnym elementem oceny potencjału gospodarczego ośrodków miejskich w kontekście analizy bazy ekonomicznej jest także określenie jej struktury. Stąd na kolejnym etapie badań na podstawie danych o wielkości zatrudnienia egzogenicznego w poszczególnych sekcjach PKD (zgodnie z nomenklaturą PKD 2007) obliczono liczbę pracujących $\mathrm{w}$ trzech sektorach produkcji, a następnie określono udział pracujących w tych sektorach w ogólnej liczbie pracujących w bazie ekonomicznej. Uwzględniono następujące sektory produkcji ${ }^{3}$ :

- przemysł (P): sekcje B, C, D, E, F;

- usługi rynkowe (R): sekcje G, H, I, J, K, L, M, N, R, S, T, U;

- usługi nierynkowe (N): sekcje O, P, Q.

Powyższe dane w ujęciu syntetycznym i w odniesieniu do grup miast (wyróżnionych ze względu na liczbę mieszkańców) przedstawiono w tabeli 2 . Z kolei analogiczne dane dla poszczególnych miast zaprezentowano w załączniku 2.

$3 \mathrm{~W}$ analizach pominięto sektor rolnictwa (sekcja A PKD) ze względu na jego marginalny udział w strukturze produkcji i zatrudnienia analizowanych ośrodków miejskich. 
Tabela 2

Struktura sektorowa bazy ekonomicznej miast województwa warmińsko-mazurskiego i podlaskiego w latach 2008 i 2015 (w proc.)

\begin{tabular}{|c|c|c|c|c|c|c|}
\hline \multicolumn{7}{|c|}{ Województwo warmińsko-mazurskie } \\
\hline \multirow{2}{*}{$\begin{array}{c}\text { Wielkość } \\
\text { miast }\end{array}$} & \multicolumn{3}{|c|}{2008} & \multicolumn{3}{|c|}{2015} \\
\hline & Przemysł & $\begin{array}{l}\text { Usługi } \\
\text { rynkowe }\end{array}$ & $\begin{array}{c}\text { Usługi } \\
\text { nierynkowe }\end{array}$ & Przemysł & $\begin{array}{l}\text { Usługi } \\
\text { rynkowe }\end{array}$ & $\begin{array}{c}\text { Usługi } \\
\text { nierynkowe }\end{array}$ \\
\hline Małe & 66,78 & 14,23 & 18,99 & 66,86 & 16,94 & 16,20 \\
\hline Średnie & 38,17 & 36,21 & 25,62 & 33,96 & 40,98 & 25,06 \\
\hline Duże & 9,21 & 72,92 & 17,87 & 6,69 & 71,02 & 22,29 \\
\hline \multicolumn{7}{|c|}{ Województwo podlaskie } \\
\hline \multirow{2}{*}{$\begin{array}{c}\text { Wielkość } \\
\text { miast }\end{array}$} & \multicolumn{3}{|c|}{2008} & \multicolumn{3}{|c|}{2015} \\
\hline & Przemysł & $\begin{array}{l}\text { Usługi } \\
\text { rynkowe }\end{array}$ & $\begin{array}{c}\text { Usługi } \\
\text { nierynkowe }\end{array}$ & Przemysł & $\begin{array}{l}\text { Usługi } \\
\text { rynkowe }\end{array}$ & $\begin{array}{c}\text { Usługi } \\
\text { nierynkowe }\end{array}$ \\
\hline Małe & 43,84 & 18,45 & 37,66 & 46,84 & 20,45 & 32,68 \\
\hline Średnie & 86,99 & 6,40 & 6,62 & 81,12 & 12,11 & 6,77 \\
\hline Duże & 21,47 & 70,03 & 8,51 & 15,70 & 59,99 & 24,31 \\
\hline
\end{tabular}

Źródło: obliczenia i opracowanie własne na podstawie danych GUS.

W przypadku małych miast województwa warmińsko-mazurskiego można zauważyć, że największą część pracujących w działalności egzogenicznej stanowili zatrudnieni w przemyśle - w obu badanych latach ponad $66 \%$ nadwyżki zatrudnionych pracowała w tym sektorze. W 2015 roku na 38 badanych ośrodków w 17 ponad połowa nadwyżki zatrudnionych pracowała w przemyśle. W ramach tego sektora zdecydowanie przeważało zatrudnienie sekcji C PKD (przetwórstwo przemysłowe). Zarówno w roku 2008, jak i w 2015 tylko ta jedna sekcja generowała około $60 \%$ (odpowiednio $59,6 \%$ i 62,1\%) ogółu miejsc pracy w zatrudnieniu nadwyżkowym.

Udział pozostałych sektorów produkcji w zatrudnieniu egzogenicznym małych miast warmińsko-mazurskiego był znacznie mniejszy, nieprzekraczający 19\%. Co charakterystyczne, o ile w roku 2008 udział sektora usług nierynkowych w zatrudnieniu egzogenicznym był o 4,7 punktów procentowych większy niż sektora usług rynkowych, o tyle na koniec badanego okresu były one na zbliżonym poziomie, z niewielką przewagą (0,74 pkt proc.) usług rynkowych. Do sekcji PKD, które generowały największą część miejsc pracy w ramach tych sektorów, należały sekcje G i H w ramach sektora usług rynkowych (w 2015 roku ich udział w całości zatrudnienia egzogenicznego wyniósł odpowiednio 7,02\% i 3,88\%) oraz sekcje Q i P w ramach sektora usług nierynkowych (w 2015 roku z udziałem w bazie ekonomicznej na poziomie 6,04\% i 5,63\%).

Sektor przemysłowy również stanowił podstawę bazy ekonomicznej małych miast województwa podlaskiego, choć w odróżnieniu od małych ośrodków miejskich warmińsko-mazurskiego jego średni udział w działalności egzogenicznej 
wszystkich badanych miast nie przekraczał 50\%. Liczba ośrodków, w których zatrudnieni w przemyśle stanowili ponad połowę bazy ekonomicznej, w roku 2008 wyniosła siedem, a w roku 2015 zmalała do pięciu. Tak duży udział zatrudnienia w tym sektorze w ogóle działalności egzogenicznej małych miast województwa podlaskiego wynikał z tego, że generuje on duże nadwyżki zatrudnionych, ale tylko w nielicznych ośrodkach. Podobnie jak w warmińsko-mazurskim sekcją PKD, która w ramach tego sektora miała największy udział w miejskiej bazie ekonomicznej, była sekcja C. W 2008 roku 41,52\%, a w roku 2015 44,17\% wszystkich pracujących w działalności egzogenicznej znalazło zatrudnienie w tym rodzaju działalności.

Drugim najważniejszym sektorem produkcji w ramach bazy ekonomicznej małych miast województwa podlaskiego były usługi nierynkowe. W obu badanych latach ponad $30 \%$ zatrudnienia nadwyżkowego dotyczyło tego sektora. Co charakterystyczne, w roku 2008 aż w 15, a w roku 2015 w 14 ośrodkach usługi nierynkowe stanowiły ponad połowę zatrudnienia egzogenicznego. Zatem sektor ten stanowi podstawę bazy ekonomicznej przede wszystkim w najmniejszych ośrodkach miejskich tego województwa, charakteryzujących się jednocześnie najmniejszą liczbą mieszkańców i niewielkim zatrudnieniem nadwyżkowym. W 2015 roku udział poszczególnych sekcji PKD w ramach tego sektora produkcji w całości zatrudnienia egzogenicznego wyniósł: $14,33 \%$ dla sekcji $\mathrm{P}, 10,56 \%$ dla sekcji O oraz $7,79 \%$ dla sekcji Q (w stosunku do roku 2008 różnice nie były w tym zakresie duże).

Najmniejsze znaczenie w strukturze bazy ekonomicznej małych miast województwa podlaskiego miały usługi rynkowe. Odpowiednio $18,45 \%$ zatrudnionych w działalności egzogenicznej w roku 2008 i 20,45\% w roku 2015 było zatrudnionych w tym sektorze produkcji. Liczba miast, w których ponad połowa zatrudnienia egzogenicznego przypadała na działalność w zakresie usług rynkowych, wyniosła natomiast pięć na początku badanego okresu i sześć na jego koniec. Uwzględniając znaczenie usług rynkowych w stymulowaniu rozwoju gospodarczego na poziomie lokalnym, można założyć, że tak niski udział tego rodzaju działalności w bazie ekonomicznej małych miast podlaskiego będzie w przyszłości w niewielkim stopniu determinował wzrost ich potencjału gospodarczego. Sekcjami PKD, które w 2015 roku w ramach omawianego sektora miały największy udział w generowaniu nadwyżek zatrudnienia, były sekcje $\mathrm{G}(9,23 \%)$ oraz $\mathrm{H}(4,3 \%)$.

Długotrwały i zrównoważony wzrost gospodarczy ośrodków miejskich oprócz nowoczesnej i konkurencyjnej struktury wymaga także wysokiego poziomu dywersyfikacji bazy ekonomicznej. Jednorodna struktura produkcji zwiększa podatność gospodarki na wahania popytu zewnętrznego, powodując wzrost ryzyka gwałtownego załamania produkcji oraz bezrobocia w okresach spadku koniunktury gospodarczej. To właśnie względna monokultura produkcyjna wobec postępujących procesów transformacji i modernizacji polskiej gospodarki stała się przyczyną stagnacji, a nawet regresu gospodarczego wielu miast w Polsce po roku 1989.

Wobec powyższego kolejny etap analiz bazy ekonomicznej małych miast województw warmińsko-mazurskiego i podlaskiego polegał na określeniu stopnia zróżnicowania ich bazy ekonomicznej. Dane w tym zakresie przedstawiono na ryc. 1 i ryc. 2. 


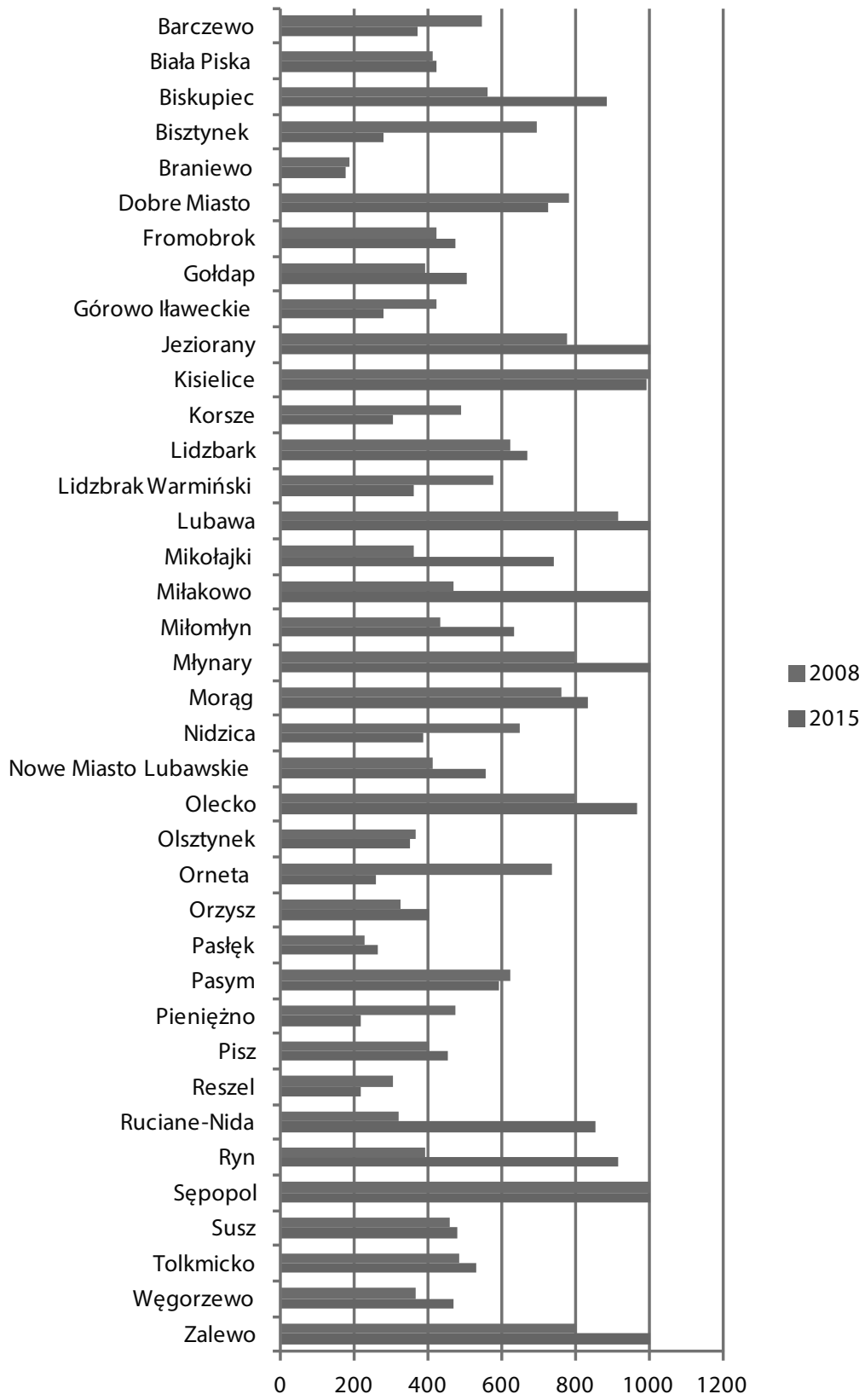

Ryc. 1. Poziom zróżnicowania struktury pracujących w sektorze egzogenicznym małych miast województwa warmińsko-mazurskiego w latach 2008 i 2015

Źródło: obliczenia i opracowanie własne na podstawie danych GUS. 




Ryc. 2. Poziom zróżnicowania struktury pracujących w sektorze egzogenicznym małych miast województwa podlaskiego w latach 2008 i 2015

Źródło: obliczenia i opracowanie własne na podstawie danych GUS.

Średni poziom dywersyfikacji bazy ekonomicznej małych ośrodków miejskich w województwie warmińsko-mazurskim mierzony za pomocą wskaźnika Amemiya (IED) kształtował się na poziomie 546 jednostek w roku 2008 i 594 jednostek w roku 2015, co świadczy o jednorodnej strukturze. Jedynie w trzech ośrodkach (Braniewo, Reszel i Pieniężno) w roku 2015 strukturę bazy ekonomicznej można było określić jako mocno zróżnicowaną, w 15 była ona zróżnicowana, a w ośmiu jednorodna. W pozostałych ośrodkach wartości wskaźnika IED były na poziomie wskazującym na mocno jednorodną bazę ekonomiczną. $\mathrm{Z}$ tego $\mathrm{w}$ aż pięciu miastach (Miłakowo, Młynary, Zalewo, Jeziorany i Sępopol) całość zatrudnienia egzogenicznego przypadała na jedną sekcję PKD - w 4 miastach była to sekcja C, 
a w jednym (Jeziorany) sekcja R. Problem względnej jednorodności bazy ekonomicznej dotyczył głównie ośrodków najmniejszych, o niewielkich rozmiarach bazy ekonomicznej i dominującym znaczeniu przemysłu w jej strukturze.

W przypadku małych ośrodków miejskich w województwie podlaskim poziom zróżnicowania bazy ekonomicznej był jeszcze mniejszy. Średnia wartość wskaźnika IED wzrosła z poziomu 568 jednostek w roku 2008 do 658 jednostek w roku 2015. Na końcu badanego okresu jedynie w przypadku dwóch miast (Łapy, Kolno) można było mówić o mocno złożonej strukturze bazy ekonomicznej. W kolejnych dziewięciu miastach była ona zdywersyfikowana, a w dwunastu jednorodna. Mocno jednorodną bazą ekonomiczną w 2015 roku charakteryzowało się pięć miast, z czego w czterech z nich (Drohiczyn, Wysokie Mazowiecki, Lipsk, Goniądz) 100\% zatrudnienia egzogenicznego ograniczało się tylko do jednej sekcji PKD (w trzech przypadkach były to sekcje zaliczane do usług nierynkowych). Analogicznie jak w województwie warmińsko-mazurskim stopień jednorodności bazy ekonomicznej rósł wraz ze zmniejszaniem się liczby mieszkańców badanych ośrodków i spadkiem rozmiarów ich sektora egzogenicznego.

\section{Podsumowanie i wnioski}

Celem prezentowanych analiz było określenie wielkości, struktury oraz poziomu zróżnicowania bazy ekonomicznej małych miast województw warmińsko-mazurskiego oraz podlaskiego oraz zmian w nich zachodzących w latach 2008-2015.

Uzyskane wyniki pozwalają stwierdzić, że sektor egzogeniczny odgrywał niewielką rolę w gospodarkach badanych miast. Przeciętna wielkość zatrudnienia nadwyżkowego w przypadku miast województwa warmińsko-mazurskiego nie przekraczała $4,5 \%$ całkowitej liczby mieszkańców tych ośrodków. W przypadku małych miast podlaskiego odsetek ten był jeszcze mniejszy i w 2015 roku wyniósł zaledwie $2,8 \%$. Tak niski udział bazy ekonomicznej w strukturze działalności gospodarczej miasta może oznaczać, że wzrost produkcji wytwarzanej w tym sektorze będzie generował impulsy zbyt słabe, aby istotnie zdynamizować wzrost gospodarczy całego miasta. Co więcej, o ile w 2015 roku w przypadku województwa warmińsko-mazurskiego średnia wielkość sektora egzogenicznego małych miast była o 0,34 pkt proc. większa w stosunku do roku 2008, o tyle w województwie podlaskim jego rozmiary w małych ośrodkach miejskich w badanym okresie zmniejszyły się średnio o 0,14 pkt. proc. W przypadku uwzględnionych w badaniu ośrodków można było także zaobserwować, że przeciętna wielkość bazy ekonomicznej zmniejszała się wraz ze spadkiem liczby mieszkańców miast.

Na możliwości wzrostu gospodarczego małych miast warmińsko-mazurskiego i podlaskiego niekorzystnie oddziaływała także struktura produkcji wytwarzanej w ramach sektora egzogenicznego. W obu województwach struktura bazy ekonomicznej była względnie trwała, $\mathrm{z}$ dominującym znaczeniem sektora przemysłowego oraz sektora usług nierynkowych. Są to rodzaje działalności, które zwykle charakteryzują się niewielką wartością dodaną oraz niskim poziomem 
konkurencyjności. W związku z tym ich oddziaływanie na lokalną gospodarkę, poza tworzeniem relatywnie nisko dochodowych miejsc pracy, jest również niewielkie. Zwłaszcza w przypadku województwa podlaskiego analiza struktury bazy ekonomicznej pozwala stwierdzić, że głównym pracodawcą w wielu badanych jednostkach był urząd gminy lub urząd miasta oraz podległe im jednostki. Biorąc pod uwagę skalę niedofinansowania jednostek samorządu terytorialnego w Polsce, trudno oczekiwać, aby działania przez nie podejmowane w krótkim okresie mogły przyczynić się do podniesienia poziomu ich atrakcyjności inwestycyjnej, poziomu konkurencyjności i w efekcie także do podniesienia poziomu wzrostu gospodarczego.

Baza ekonomiczna małych miast obu województw charakteryzuje się także niskim poziomem zróżnicowania. Większość zatrudnienia nadwyżkowego przypada na niewielką liczbą sekcji PKD (często ogranicza się tylko do jednej sekcjiprzetwórstwa przemysłowego), co zwiększa ryzyko załamania produkcji i recesji lokalnych gospodarek na wypadek spadku koniunktury gospodarczej i spadku popytu zewnętrznego na dobra wytwarzane w ramach sektora egzogenicznego. Co więcej, w obu badanych regionach poziom zróżnicowania bazy ekonomicznej małych miast nieznacznie zmalał.

Uwzględniając znaczenie ośrodków miejskich w stymulowaniu wzrostu i rozwoju gospodarczego regionów, a także biorąc pod uwagę wyniki prezentowanych analiz, można z dużym prawdopodobieństwem założyć, że jedną z przyczyn niskiego poziomu wzrostu gospodarczego województw warmińsko-mazurskiego i podlaskiego była relatywnie słabo rozwinięta baza ekonomiczna miast. Jednocześnie $\mathrm{w}$ analizowanym okresie nie można było zaobserwować korzystnych zmian ani w wielkości, ani w strukturze czy poziomie zróżnicowania bazy ekonomicznej, co pozwala przypuszczać, że w przyszłości istniejące dysproporcje rozwojowe między województwami warmińsko-mazurskim i podlaskim a resztą kraju nie ulegną zmniejszeniu.

\section{Bibliografia}

Bogdański M. (2017), Wybrane czynniki ksztattujące bazę ekonomiczna małych i średnich miast w Polsce, ,Samorząd Terytorialny”, 3 (315).

Brol R. (2004), Miasto - społeczeństwo, gospodarka, przestrzeń [w:] R. Brol (red.), Ekonomika i zarzadzanie miastem, Wyd. Akademii Ekonomicznej im. Oskara Langego we Wrocławiu, Wrocław.

Christofakis M., Gkouzos A. (2014), Exploration of Localness in the Context of Economic Base: Accessing Evidence From Greek Prefectures, „Urban \& Regional Development Studies", 26.

Czornik M. (2004), Miasto. Ekonomiczne aspekty funkcjonowania, Wyd. Akademii Ekonomicznej im. Karola Adamieckiego w Katowicach, Katowice.

David Q., Peeters D.,Van Hamme G., Vandermotten C. (2013), Is Bigger Better? Economic Performance of European Cities, 1960-2009, „Cities”, 35. 
Elsasser H. (1998), Ist eine Kleinstadt mehr als eine kleine Stadt? [w:] E.-M. Munduch (Hrsg.), Kleinstädte - Motoren im ländlichen Raum, Tagungsband, Murau.

Grossmann K., Bontje M., Haase A., Mykhnenko V. (2013), Shrinking Cities: Notes for the Further Research Agenda, „Cities”, 35.

Jerczyński M. (1971), Metody pośrednie identyfikacji i pomiaru bazy ekonomicznej miast [w:] Baza ekonomiczna i struktura funkcjonalna miast, Instytut Geografii PAN, Warszawa.

Knapik W. (2010), Zmiany struktury funkcjonalnej miast województwa łódzkiego w latach 2000-2008 [w:] M. Wójcik (red.), Studia nad baza ekonomiczna miast i rynkiem pracy w województwie tódzkim, Karpacki Instytut Rozwoju Regionalnego, Nowy Sącz.

Korcelli P. (2007), Podstawowe węzły uktadu osadniczego w Polsce na tle europejskiego systemu osadniczego (Aglomeracje-Metropolie), PAN, Komitet Przestrzennego Zagospodarowania Kraju, Warszawa.

Messerli, P. (1998), Sind die Alpenstädte besondere Städte? [Are the alpine towns special cities?], "Revue de géographie alpine", 87.

Przybyła K. (2010), Wpływ specjalnych stref ekonomicznych na kształtowanie się bazy ekonomicznej miast, Wyd. Uniwersytetu Przyrodniczego we Wrocławiu, Wrocław.

Rutland T., O'Hagan S. (2007), The Growing Localness of the Canadian City, or, On the Continued (Ir)relevance of Economic Base Theory, „Local Economy”, 2 (22).

Sokołowski D. (2008), Baza ekonomiczna większych miast w Polsce w okresie transformacji systemowej, „Przegląd Geograficzny”, 80.

Stawasz D. (2016), Wspótczesne dylematy zarządzania rozwojem miast, Wyd. Uniwersytetu Łódzkiego, Łódź.

Suliborski, A. (2002), Funkcjonalne przemiany i integracja systemu miast $w$ regionie tódzkim [w:] A. Suliborski (red.), Struktury i procesy ksztattujace tódzki region społeczno-gospodarczy, Zakład Ekonomiki Regionalnej i Ochrony Środowiska, Fundacja Inkubator, Łódź.

Szlachta J. (2011), Ośrodki subregionalne w Polsce - identyfikacja [w:] W. Dziemianowicz, J. Szlachta, K. Szmigiel-Rawska (red.), Subregionalne bieguny wzrostu w Polsce, Wydział Geografii i Studiów Regionalnych Uniwersytetu Warszawskiego, Warszawa.

Thulin P. (2014), Local Multiplier and Economic Base Analysis, Working Paper No. 29, Swedish Entrepreneurship Forum.

The Role of Small and Medium-Sized Towns (2006), Austrian Institute for Regional Studies and Spatial Planning, Vienna.

Walkiewicz D. (2006), Przemiany struktury funkcjonalnej miast wojewódzkich w latach 1975-1995, Wyd. Uniwersytetu Łódzkiego, Łódź. 
Załącznik 1

Rozmiary bazy ekonomicznej w małych miastach województwa warmińsko-mazurskiego w latach 2008 i 2015






\begin{tabular}{|l|r|r|r|r|r|r|}
\hline Reszel & 275 & 5,55 & 171 & 3,67 & -104 & $-1,89$ \\
\hline Ruciane-Nida & 161 & 3,41 & 71 & 1,54 & -90 & $-1,87$ \\
\hline Ryn & 7 & 0,24 & 48 & 1,64 & 40 & 1,40 \\
\hline Sępopol & 36 & 1,78 & 26 & 1,30 & -10 & $-0,48$ \\
\hline Susz & 266 & 4,75 & 140 & 2,47 & -126 & $-2,28$ \\
\hline Tolkmicko & 26 & 0,95 & 13 & 0,47 & -13 & $-0,48$ \\
\hline Węgorzewo & 601 & 5,21 & 546 & 4,72 & -56 & $-0,49$ \\
\hline Zalewo & 425 & 20,11 & 444 & 20,30 & 19 & 0,19 \\
\hline
\end{tabular}

Źródło: opracowanie i obliczenia własne.

Rozmiary bazy ekonomicznej w małych miastach województwa podlaskiego w latach 2008 i 2015






\begin{tabular}{|l|r|r|r|r|r|c|}
\hline Suraż & 16 & 1,63 & 16 & 1,58 & 0 & $-0,05$ \\
\hline Szczuczyn & 79 & 2,21 & 62 & 1,79 & -17 & $-0,42$ \\
\hline Tykocin & 42 & 2,18 & 22 & 1,10 & -20 & $-1,08$ \\
\hline Wasilków & 384 & 4,06 & 301 & 2,81 & -82 & $-1,25$ \\
\hline $\begin{array}{l}\text { Wysokie } \\
\text { Mazowieckie }\end{array}$ & 137 & 1,47 & 38 & 0,41 & -98 & $-1,07$ \\
\hline Zabłudów & 38 & 1,54 & 44 & 1,75 & 6 & 0,21 \\
\hline
\end{tabular}

Źródło: opracowanie i obliczenia własne.

Załącznik 2

Struktura sektorowa bazy ekonomicznej małych miast województwa warmińsko-mazurskiego w latach 2008 i 2015 (w proc.)

\begin{tabular}{|l|c|c|c|c|c|c|}
\hline \multirow{2}{*}{ Miasto } & \multicolumn{3}{|c|}{$\mathbf{2 0 0 8}$} & \multicolumn{2}{c|}{$\mathbf{2 0 1 5}$} \\
\cline { 2 - 7 } & Przemysi & $\begin{array}{c}\text { Usługi } \\
\text { rynkowe }\end{array}$ & $\begin{array}{c}\text { Usługi } \\
\text { nie- } \\
\text { rynkowe }\end{array}$ & Przemysl & $\begin{array}{c}\text { Usługi } \\
\text { rynkowe }\end{array}$ & $\begin{array}{c}\text { Usługi } \\
\text { nierynkowe }\end{array}$ \\
\hline Barczewo & 30,18 & 16,90 & 22,87 & 12,26 & 49,06 & 38,68 \\
\hline Biała Piska & 2,98 & 29,82 & 33,16 & 7,08 & 56,03 & 36,89 \\
\hline Biskupiec & 33,77 & 30,70 & 16,52 & 94,25 & 5,75 & 0,00 \\
\hline Bisztynek & 18,27 & 13,94 & 19,23 & 45,61 & 12,20 & 26,58 \\
\hline Braniewo & 20,61 & 31,96 & 42,03 & 0,00 & 46,67 & 53,33 \\
\hline Dobre Miasto & 58,96 & 14,80 & 20,78 & 84,96 & 15,04 & 0,00 \\
\hline Frombork & 3,72 & 7,99 & 10,04 & 47,85 & 52,15 & 0,00 \\
\hline Gołdap & 45,58 & 22,27 & 29,20 & 85,34 & 6,13 & 8,53 \\
\hline Górowo Iławeckie & 27,63 & 13,03 & 43,03 & 0,00 & 0,00 & 87,48 \\
\hline Jeziorany & 14,48 & 9,85 & 21,62 & 0,00 & 100,00 & 0,00 \\
\hline Kisielice & 20,33 & 2,03 & 48,37 & 0,00 & 0,33 & 99,67 \\
\hline Korsze & 33,05 & 21,58 & 0,00 & 47,79 & 45,72 & 6,48 \\
\hline Lidzbark & 46,90 & 23,12 & 15,20 & 81,94 & 18,06 & 0,00 \\
\hline Lidzbark Warmiński & 49,96 & 22,55 & 26,80 & 84,81 & 8,48 & 6,72 \\
\hline Lubawa & 70,12 & 18,69 & 8,19 & 100,00 & 0,00 & 0,00 \\
\hline Mikołajki & 19,18 & 8,37 & 8,18 & 6,09 & 86,29 & 6,91 \\
\hline Miłakowo & 49,77 & 0,00 & 37,21 & 100,00 & 0,00 & 0,00 \\
\hline Miłomłyn & 33,25 & 1,26 & 34,01 & 18,81 & 2,54 & 78,64 \\
\hline Młynary & 49,61 & 0,00 & 15,58 & 100,00 & 0,00 & 0,00 \\
\hline Morąg & 52,70 & 21,67 & 23,68 & 91,55 & 8,45 & 0,00 \\
\hline Nidzica & 45,17 & 23,88 & 27,61 & 59,60 & 33,47 & 6,93 \\
\hline
\end{tabular}




\begin{tabular}{|l|r|r|r|r|r|r|}
\hline $\begin{array}{l}\text { Nowe Miasto } \\
\text { Lubawskie }\end{array}$ & 41,63 & 29,25 & 25,37 & 73,32 & 18,02 & 8,66 \\
\hline Olecko & 48,76 & 19,34 & 28,71 & 98,86 & 1,14 & 0,00 \\
\hline Olsztynek & 30,02 & 18,09 & 14,74 & 55,81 & 24,43 & 19,76 \\
\hline Orneta & 54,90 & 19,37 & 19,61 & 12,07 & 64,17 & 23,77 \\
\hline Orzysz & 18,34 & 26,78 & 27,22 & 0,00 & 66,95 & 33,05 \\
\hline Pasłęk & 40,89 & 30,39 & 25,88 & 40,16 & 49,30 & 10,54 \\
\hline Pasym & 14,95 & 13,62 & 41,53 & 0,00 & 23,61 & 76,39 \\
\hline Pieniężno & 11,11 & 24,92 & 38,44 & 14,42 & 48,83 & 36,76 \\
\hline Pisz & 41,81 & 19,53 & 25,22 & 16,12 & 10,65 & 73,22 \\
\hline Reszel & 48,02 & 9,47 & 32,71 & 51,04 & 3,66 & 45,30 \\
\hline Ruciane-Nida & 8,08 & 23,40 & 31,48 & 0,00 & 7,55 & 92,45 \\
\hline Ryn & 29,33 & 10,67 & 16,17 & 95,68 & 4,32 & 0,00 \\
\hline Sępopol & 0,00 & 2,70 & 37,84 & 0,00 & 0,00 & 100,00 \\
\hline Susz & 45,47 & 22,73 & 14,77 & 70,23 & 5,51 & 24,26 \\
\hline Tolkmicko & 5,73 & 2,75 & 13,76 & 0,00 & 33,70 & 66,30 \\
\hline Węgorzewo & 20,44 & 24,76 & 52,89 & 11,87 & 6,76 & 81,37 \\
\hline Zalewo & 75,47 & 9,42 & 7,04 & 100,00 & 0,00 & 0,00 \\
\hline
\end{tabular}

Źródło: opracowanie i obliczenia własne.

Struktura sektorowa bazy ekonomicznej małych miast województwa podlaskiego w latach 2008 i 2015 (w proc.)

\begin{tabular}{|l|c|c|c|c|c|r|}
\hline \multirow{2}{*}{ Miasto } & \multicolumn{3}{|c|}{$\mathbf{2 0 0 8}$} & \multicolumn{2}{c|}{$\mathbf{2 0 1 5}$} \\
\cline { 2 - 7 } & Przemysl & $\begin{array}{c}\text { Usługi } \\
\text { rynkowe }\end{array}$ & $\begin{array}{c}\text { Usługi } \\
\text { nie- } \\
\text { rynkowe }\end{array}$ & Przemysi & $\begin{array}{c}\text { Usługi } \\
\text { rynkowe }\end{array}$ & $\begin{array}{c}\text { Usługi } \\
\text { nierynkowe }\end{array}$ \\
\hline Brańsk & 95,96 & 0,00 & 4,04 & 83,75 & 3,75 & 12,50 \\
\hline Choroszcz & 100,00 & 0,00 & 0,00 & 45,02 & 34,65 & 20,33 \\
\hline Ciechanowiec & 1,71 & 0,00 & 98,29 & 0,00 & 19,72 & 80,28 \\
\hline Czarna Białostocka & 94,98 & 5,02 & 0,00 & 95,92 & 4,08 & 0,00 \\
\hline Dąbrowa Białostocka & 0,00 & 48,09 & 51,91 & 0,00 & 28,59 & 71,41 \\
\hline Drohiczyn & 0,00 & 100,00 & 0,00 & 0,00 & 100,00 & 0,00 \\
\hline Goniądz & 0,00 & 19,86 & 77,64 & 0,00 & 0,00 & 100,00 \\
\hline Jedwabne & 0,00 & 17,02 & 82,98 & 31,18 & 68,82 & 0,00 \\
\hline Kleszczele & 83,11 & 0,00 & 16,89 & 37,60 & 15,80 & 46,60 \\
\hline Knyszyn & 0,00 & 33,08 & 66,92 & 0,00 & 35,76 & 64,24 \\
\hline Kolno & 0,00 & 33,80 & 66,20 & 20,94 & 13,16 & 65,89 \\
\hline
\end{tabular}




\begin{tabular}{|l|r|r|r|r|r|r|}
\hline Lipsk & 0,00 & 0,00 & 100,00 & 0,00 & 0,00 & 100,00 \\
\hline Łapy & 95,02 & 0,12 & 4,86 & 28,75 & 41,04 & 30,21 \\
\hline Mońki & 9,62 & 8,40 & 81,98 & 44,34 & 3,86 & 51,80 \\
\hline Nowogród & 0,00 & 70,65 & 29,35 & 0,00 & 35,50 & 64,50 \\
\hline Rajgród & 0,00 & 0,00 & 0,00 & 0,00 & 76,63 & 20,32 \\
\hline Sejny & 0,00 & 28,06 & 71,94 & 0,00 & 22,75 & 77,25 \\
\hline Siemiatycze & 33,13 & 51,57 & 15,31 & 67,32 & 20,66 & 12,02 \\
\hline Sokółka & 57,31 & 17,92 & 24,77 & 81,19 & 0,18 & 18,63 \\
\hline Stawiski & 0,00 & 0,72 & 99,28 & 0,00 & 45,92 & 54,08 \\
\hline Suchowola & 0,00 & 50,35 & 49,65 & 0,00 & 65,05 & 34,95 \\
\hline Supraśl & 0,00 & 36,46 & 63,54 & 0,00 & 60,00 & 40,00 \\
\hline Suraż & 0,00 & 0,00 & 100,00 & 0,00 & 17,89 & 82,11 \\
\hline Szczuczyn & 0,00 & 0,00 & 100,00 & 0,00 & 8,27 & 91,73 \\
\hline Tykocin & 0,00 & 0,00 & 100,00 & 0,00 & 80,56 & 19,44 \\
\hline Wasilków & 98,66 & 0,00 & 1,34 & 57,65 & 21,33 & 21,02 \\
\hline Wysokie Mazowieckie & 12,49 & 52,34 & 35,17 & 0,00 & 0,00 & 100,00 \\
\hline Zabłudów & 0,00 & 6,60 & 93,40 & 0,00 & 21,72 & 78,28 \\
\hline
\end{tabular}

Źródło: opracowanie i obliczenia własne. 